\title{
Modeling the volcanic ash dispersion and deposition from El Reventador volcano eruption in Ecuador on November 3rd 2002
}

\author{
R. Parra \\ Instituto de Investigaciones Atmosféricas, \\ Grupo de Investigación sobre la Ceniza Volcánica en el Ecuador, \\ Universidad San Francisco de Quito, Ecuador
}

\begin{abstract}
In Ecuador there are at least 25 potentially active volcanoes. Some have emitted ash and aerosols producing critical air pollution events, with significant health and socio-economic effects. The Distrito Metropolitano de Quito (DMQ), in the Andean region of Ecuador, is highly threatened by three volcanoes: El Reventador, Guagua Pichincha and Cotopaxi. El Reventador volcano, located at about $90 \mathrm{~km}$ east of Quito, erupted on November 3rd 2002 producing a column of ash $17 \mathrm{~km}$ high. The lower part of the ash cloud, below $16 \mathrm{~km}$, was directed towards Quito, whereas the upper portion traveled to the east. Air pollutant concentrations exceeded several times the national regulation for $\mathrm{PM}_{10}$, generating danger for the entire population. Between $13 \mathrm{~h} 00$ and $16 \mathrm{~h} 00$ local time, fine ash settled down in Quito and its eastern valleys, leaving an ash layer 3 to $5 \mathrm{~mm}$ thick. This event was numerically simulated coupling the Eulerian Weather Research and Forecasting (WRF) and the volcanic ash dispersion Fall3d models. A semi-qualitative assessment of the modeled ash cloud dynamics and deposition showed that modeled results were valid. WRF and Fall3d are used daily in the DMQ to forecast the ash fall trajectory and ash fall from these three volcanoes, under specific assumptions of eruption time and ash column height.

Keywords: Distrito Metropolitano de Quito, WRF, Fall3d, forecasting, risk management.
\end{abstract}




\section{Introduction}

Volcanic ash emissions can produce critical air pollution events, with substantial health and socio-economic effects. Inhaling volcanic ash can create breathing problems, especially for people with pre-existing lung diseases. In addition, it can produce eye irritation, leading to conjunctivitis and corneal abrasion. Heavy ash falls can cause roof collapse and reduce visibility, resulting in traffic accidents. Roads become slippery when covered with ash fall [1]. Volcanic ash is also a serious hazard to aviation and can cause jet engines to suddenly fail in flight. Encounters with high-concentration ash clouds can diminish visibility and damage flight control systems [2].

In order to protect public health and improve risk management, regions that are potentially affected by volcanic ash emissions, should count on information regarding to the possible dispersion trajectory and deposition pattern of volcanic ash.

In Ecuador there are at least 25 potentially active volcanoes (Fig. 1). Some of them have emitted ash and aerosols producing air pollution events, with concentrations exceeding several times the national regulation for $\mathrm{PM}_{10}$, generating danger for the entire population. Volcanoes are a research priority for atmospheric scientists as potential sources of air pollution.

In the Distrito Metropolitano de Quito (DMQ), the capital of Ecuador, the two most recent and important events happened in October 1999 and November 2002, when the Pichincha and El Reventador volcanoes erupted, respectively. In 2002 there was not an air quality network in Quito and air quality information was very scarce. Information from one monitoring place indicates than within the urban area, during both eruptions, the 24-hour mean for $\mathrm{PM}_{10}$ reached concentrations greater than the ambient level of $500 \mu \mathrm{g} \mathrm{m}^{-3}$ set for emergency situations, according with the national regulation [3]. These eruptions and other concerns about public health, deterioration of monuments and cultural heritage in the Historic Center of Quito, were the main reasons to install a permanent air quality network, which provides official information since 2004.

In 2008 the Municipality of Quito drew up a contingency plan for critical air pollution critical. According to this document, the next potential critical air pollution event in Quito will probably happen due to volcanic ash rather than to anthropogenic emissions. Based on a risk assessment, the DMQ is highly threatened by three volcanoes: El Reventador, Guagua Pichincha and Cotopaxi. These volcanoes are located less than $100 \mathrm{~km}$ away from Quito [3].

El Reventador, a stratovolcano located at about $90 \mathrm{~km}$ east of Quito, erupted on November 3rd 2002 with little precursory warning, producing a column of ash $17 \mathrm{~km}$ high. The lower part of the ash cloud, below $16 \mathrm{~km}$, was directed towards Quito whereas the upper portion traveled to the east, toward the Amazon region. The plume's splitting in two portions was explained by a strong wind shear between $14 \mathrm{~km}$ and $16 \mathrm{~km}$ altitude [4].

The Volcanic Explosion Index (VEI) of this event was 4, this being the most important in Ecuador since the 1886 eruption of the Tungurahua volcano 
$(\mathrm{VEI}=4)$. The uncompacted tephra fall volume was estimated between 0.15 and $0.28 \mathrm{~km}^{3}[5,6]$.

According to Hall et al. [7], chronologically at local times (LT, LT = Coordinated Universal Time (UTC) - 5h) the most important events during El Reventador eruption were the following:

- 05h30: workers reported a steam column 2-3 km high

- 07h15: pilots from a commercial airline reported an ash plume in the direction of El Reventador volcano

- 07h45: witnesses reported increased intensity of the eruptive column, reaching about $6 \mathrm{~km}$ above the cone and moving in the southwest direction

- 09h12: the main eruption began. The column rose 16 to $17 \mathrm{~km}$ above the vent

- 13h00: the ash cloud reached the InterAndean Valley and the city of Quito, causing almost total obscurity by the late afternoon. It left a layer up to 3 to 5 $\mathrm{mm}$ thick of fine gray ash. Some closer to the volcano received up to $3 \mathrm{~cm}$ of ash. Most inhabitants complained about the strong odor due to $\mathrm{SO}_{2}$ and $\mathrm{H}_{2} \mathrm{~S}$ emissions.

Quito's International Airport closed officially at 12h45 LT. Several deaths and injuries were attributed to falling off roofs while performing roof cleaning [7].

Emission, transport and sedimentation of volcanic ash are complex. Most of the fine ash injected during an eruption typically aggregate because of complex interactions [8]. Aggregation can occur under different conditions and in multiple regions of the plume and in the ash cloud [9]. A major consequence of aggregation is the change of the aerodynamic behavior and the residence time of fine particle [10].

To analyze the validity of models currently available, this event was numerically simulated coupling the Eulerian Weather Research and Forecasting (WRF) model [11] and the volcanic ash dispersion model Fall3d [12, 13].

WRF is a latest-generation Eulerian non-hydrostatic model, used for meteorological forecasting and weather research. It is a fully compressible model that solves the equations of atmospheric motion. It is applicable to global, mesoscale, regional and local scales. WRF allows the numerical processing in parallel with great efficiency [14]. It uses three dimensional (3d) domains for the $\mathrm{x}, \mathrm{y}$ and sigma directions. Sigma values define the atmospheric vertical structure, with flat surfaces for upper layers of the atmosphere and surfaces that take gradually the shape of the terrain, as layers move near to the ground.

Fall3d is a $3 \mathrm{~d}$ time-dependent Eulerian model for the transport and deposition of volcanic ash and lapilli. It solves the advection-diffusion-sedimentation equation on a structured terrain-following grid using a second-order finitedifferences explicit scheme [10].

\section{Method}

Applying an off-line approach, the WRF model (version 3.1.1), was used to generate wind fields and other meteorological variables to be fed into Fall3d. Meteorological simulations were performed using a master domain of 100x100 
cells, each of $27 \times 27 \mathrm{~km}$; and two nested subdomains (Fig. 2). The second subdomain has $82 \times 67$ cells of $3 \mathrm{~km}$ by side each one, and 35 vertical levels. This subdomain was centered over the region of the DMQ.

The model pressure top was set to $50 \mathrm{hPa}$ (approximately at $22 \mathrm{~km}$ ). Initial and boundary conditions were obtained using NCEP FNL (Final) Operational Global Analysis data [15].

Meteorology was simulated from 3 Nov 2002 at 00h00 UTC (2 Nov 2002 at $19 \mathrm{~h} 00 \mathrm{LT}$ ) to 5 Nov 2002 at $23 \mathrm{~h} 00$ UTC. To warm up the meteorological model, there is a time-lag of 10 hours between the beginning of the meteorological simulation and the beginning of the eruption, which was assumed to have started at $10 \mathrm{~h} 00 \mathrm{UTC}(05 \mathrm{~h} 00 \mathrm{LT})$.

For the WRF simulation, the following physical parameterization was applied: [16] the double moment 6-class scheme for microphysics, the rrtm scheme for longwave radiation, the Duhdia scheme for shortwave radiation, the MoninObuknov scheme for the surface-layer option, the 5-layer thermal diffusion scheme for the land-surface option and the Grell-Devenyi ensemble scheme for the cumulus option.

Fall3d (version 6.1) was used to perform ash volcanic transport and sedimentation modeling. The domain for the Fall3d simulation was similar to the second subdomain used for the meteorology simulation. Hence, it used an $82 \times 67$ grid with $20000 \mathrm{~m}$ in height, divided in layers of $500 \mathrm{~m}$ each one. Fall3d interpolates WRF's results previously to perform ash dispersion simulation. Height surfaces follow the terrain shape. This version of Fall3d does not take into account particle aggregation effects.

After the eruption, Delpit et al. [5] collected tephra samples at different distances (proximal part $\sim 55 \mathrm{~km}$, intermediate part $\sim 75 \mathrm{~km}$ and distal part $\sim 85$ $\mathrm{km}$ ) and report fractions between $90 \mu \mathrm{m}$ (grain size $\varnothing=3.4$ ) to $250 \mu \mathrm{m}$ (grain size $\varnothing=2$ ). Observation of tephra revealed 3 textural classes: (1) juvenile glass, with mainly whitish grains and dark in lesser extend; (2) free crystal, mainly plagioclase and few pyroxene; and (3) lithic grains. Horwell [17] collected a a sample of ash in the valley of Tumbaco, near Quito, and report a mean diameter of $44 \mu \mathrm{m}(\varnothing=4.5)$. Based on this information, the tephra granulometry distribution for simulation was assumed as bigaussian, using mean values of 2.7 and 4.5 for $\varnothing$, divided in 8 particle classes.

For the source type, the Suzuki option [18] was chosen in the Fall3d model, together with the fit proposed by Mastin et al. [19]. The method by Mastin estimates the ash emission according to a statistical fitting between column height and ash emission rate obtained with data from 34 well studied volcanic eruptions. This option in the Fall3d model is helpful because most of the times column height is the first known or estimated variable when a volcanic eruption takes place.

The column height was modeled assuming that it reached $3 \mathrm{~km}$ over the vent, at about $05 \mathrm{~h} 00 \mathrm{LT}$ and it rose to $17 \mathrm{~km}$ by $09 \mathrm{~h} 00 \mathrm{LT}$. For the following 9 hours it was assumed that the final height of $17 \mathrm{~km}$ did not vary. The mass eruption resulting from the Mastin fit was approximately $0.3 \mathrm{~km}^{3}$. 


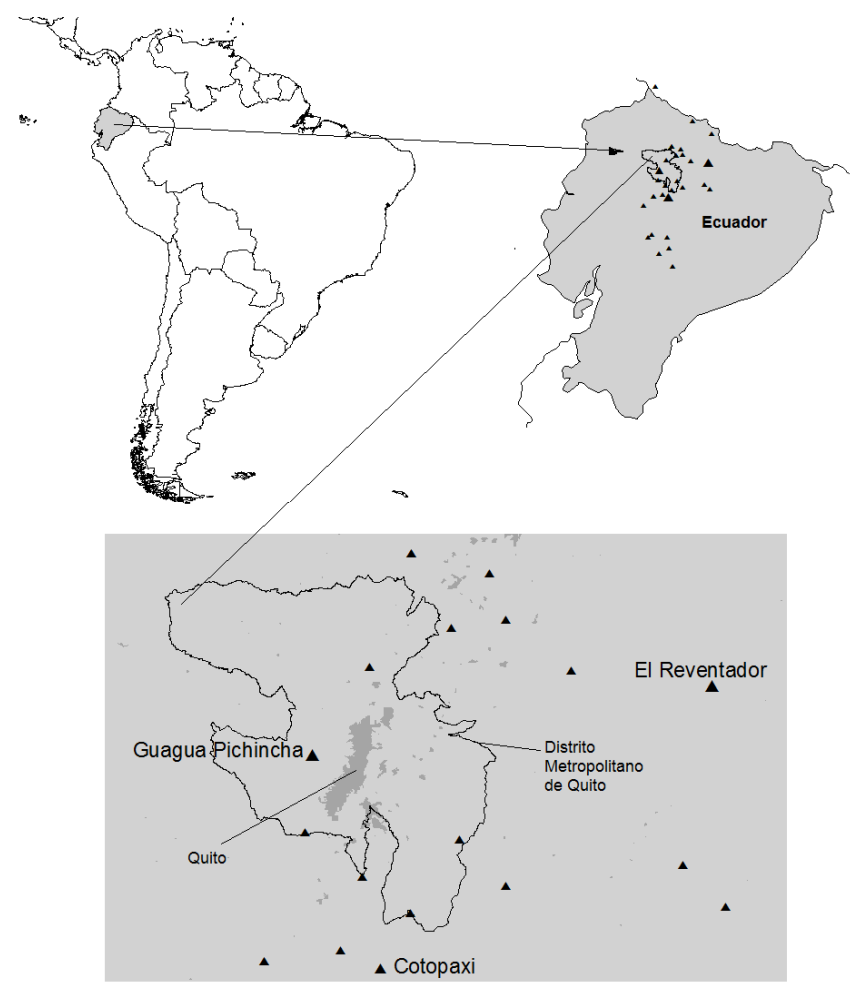

Figure 1: Location of Ecuador in South America (upper left) and volcanoes within Ecuador (black triangles).

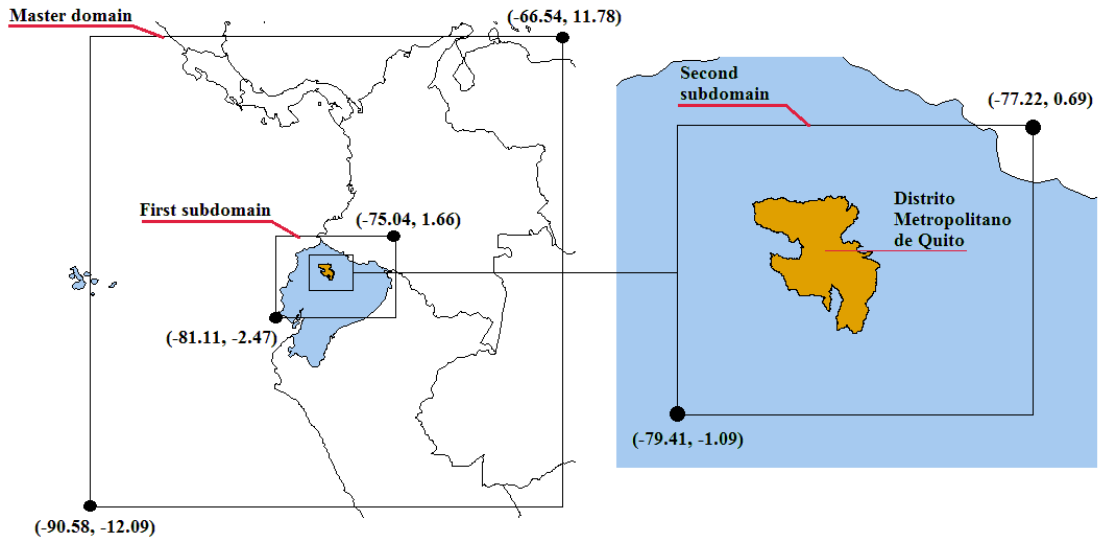

Figure 2: $\quad$ Model simulation domains: d01 master domain (100 x 100 cells, $27 \times 27 \mathrm{~km}), \mathrm{d} 02$ first subdomain $(76 \times 52$ cells, 9x9 km), d03 second subdomain $(82 \times 67$ cells, $3 \times 3 \mathrm{~km})$. 


\section{Results}

Fig. 3 shows the locations of Quito's air quality automatic monitoring stations. Seven of them (Car, Cot, Jip. Bel, Cen, Cam and Gua) are sited over the urban region of Quito; one of them (Tum) is located in the valley of Tumbaco, east of Quito; and the last one (Chi) in the valley of Los Chillos, southeast of Quito. These locations indicate in the following figures, the urban area of Quito and surroundings valleys.

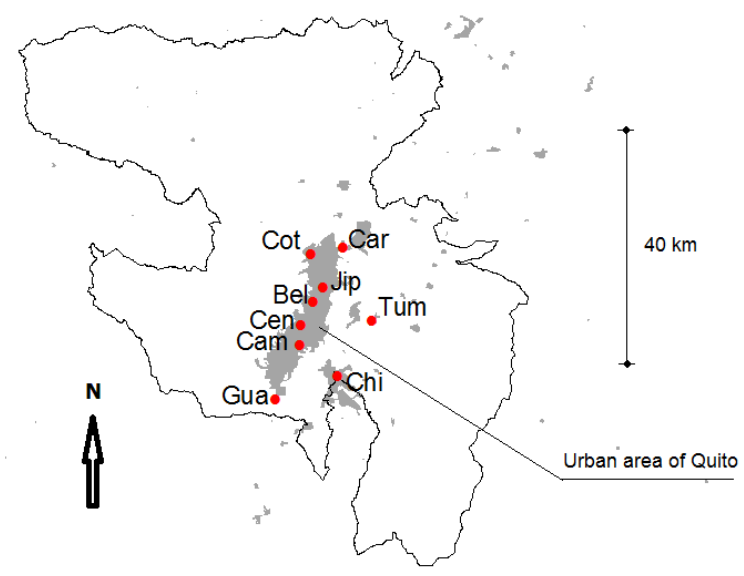

Figure 3: Locations of the automatic stations within the Quito air quality network, installed in 2003: Car (Carapungo), Cot (Cotocollao), Jip (Jipijapa), Bel (Belisario), Cen (Centro Histórico), Cam (Camal), Gua (Guamani), Tum (valley of Tumbaco), Chi (valley of Los Chillos). Grey zones represent the urban area of Quito and inhabited areas.

At 10h00 LT model results show ash moving at 5000 masl towards the west (Fig. 4). At $12 \mathrm{~h} 00$ the ash cloud reaches the northeast region of the urban area of Quito. Dots show the location of the air quality stations depicted in Fig. 3. At 13 h00 the ash cloud covered completely the valley of Tumbaco, most of the urban area of Quito, and partially the valley of Los Chillos. At $24 \mathrm{~h} 00$ an ash layer of 1-5 mm thick was formed on most of the urban area of Quito (Fig. 5).

The National Oceanic and Atmospheric Administration [20], through the Volcanic Ash Advisory Center (VAAC) in Washington, provides volcanic ash dispersion graphs when a plume is clearly identified by satellite imagery. Whenever there is an on-going eruption, the regional VAAC makes use of direct observations by pilots, satellite imagery and modeling, to issue warning bulletins and to forecast the short-term evolution of the cloud. These graphs do not provide ash concentrations. Also, graphs are not provided when satellites are not able to identify volcanic ash due to cloudiness. In America, Washington's 

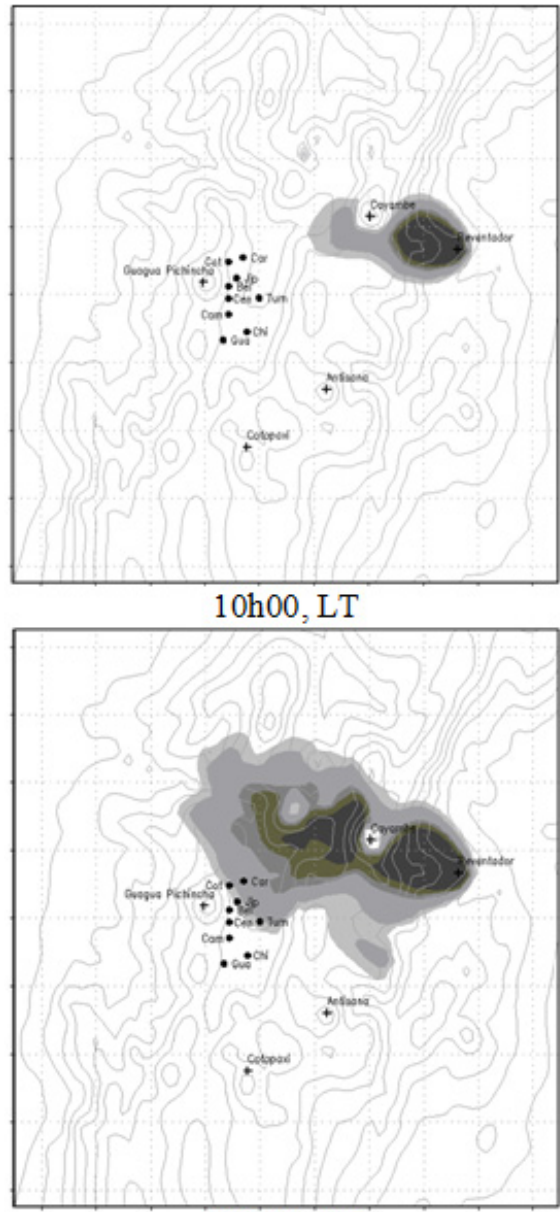

$13 \mathrm{~h} 00, \mathrm{LT}$

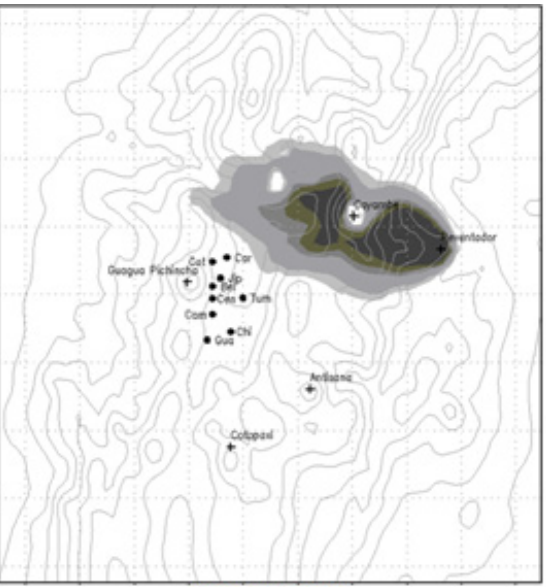

$12 \mathrm{~h} 00, \mathrm{LT}$

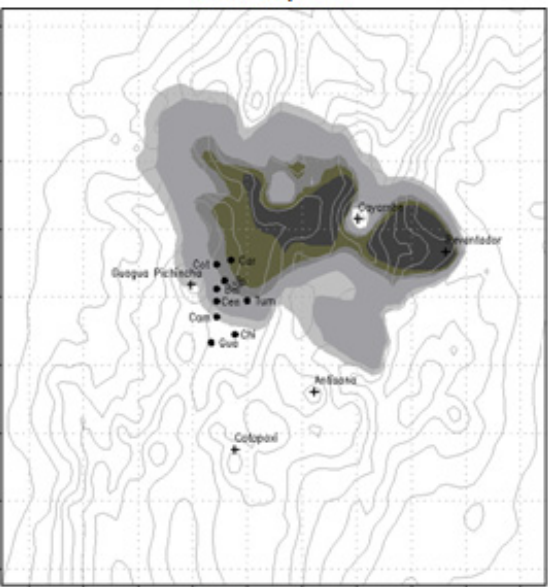

$14 \mathrm{~h} 00, \mathrm{LT}$

\section{$\begin{array}{llllllll}0.05 & 0.1 & 0.2 & 0.4 & 0.6 & 1.0 & 1.2 & 1.4\end{array}$}

Figure 4: Shaded regions correspond to ash concentrations $\left(\mathrm{g} / \mathrm{m}^{3}\right)$ at 5000 masl that reached Quito by $12 \mathrm{~h} 00 \mathrm{LT}$. Black dots show the location of air quality stations within Quito, installed in 2003. Black contour lines depict topography (masl). 

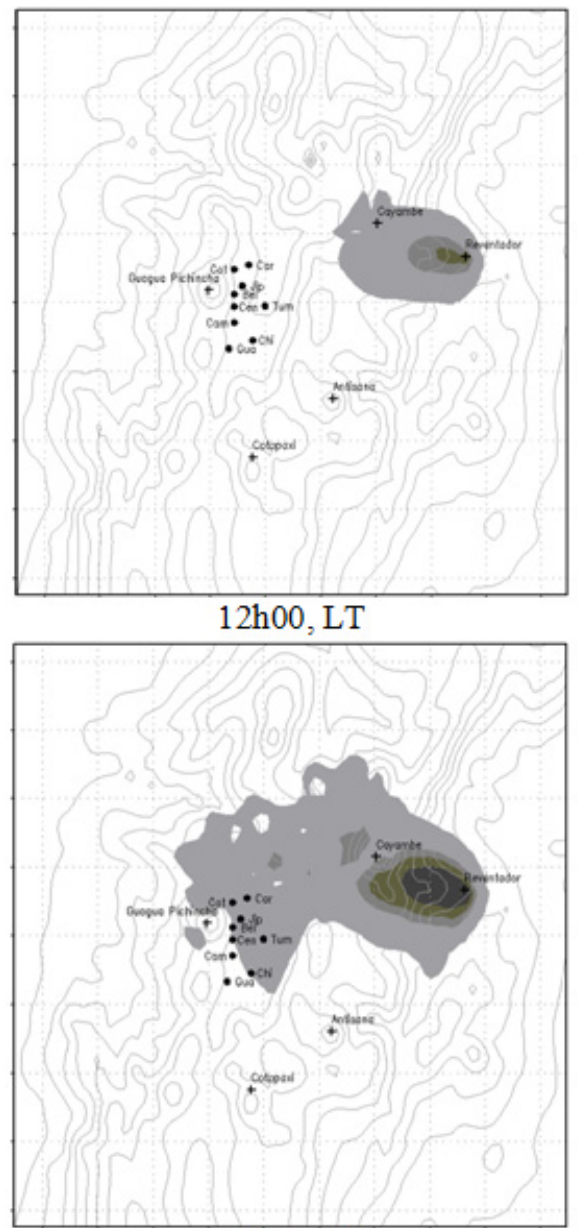

$18 \mathrm{~h} 00, \mathrm{LT}$

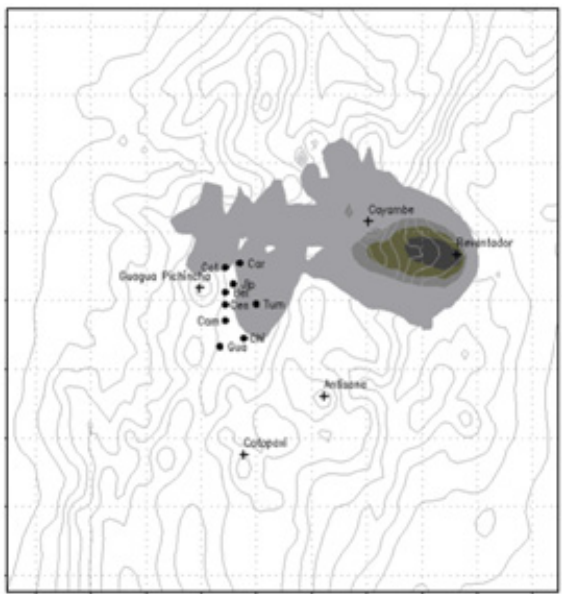

$16 \mathrm{~h} 00, \mathrm{LT}$

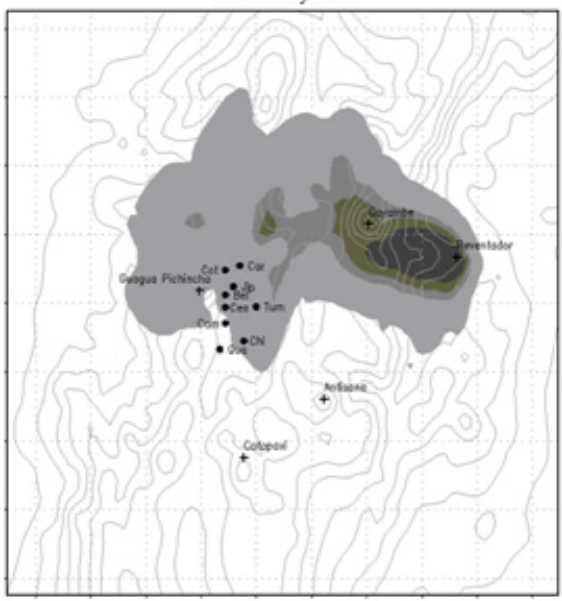

23h00, LT

$\begin{array}{llllll}0.05 & 0.5 & 1.0 & 2.0 & 4.0 & 8.0\end{array}$

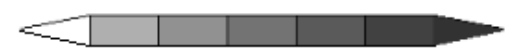

Figure 5: Ash layer thickness $(\mathrm{cm})$ began to settle at $16 \mathrm{~h} 00 \mathrm{LT}$ in the surrounding areas in the northeast region of Quito. Black dots show the location of air quality stations in Quito, installed in 2003. Black contour lines depict topography (masl).

VAAC provides coverage for the Continental of United States, Central America, the Caribbean and the upper part of South America, where Ecuador is located.

Fig. 6a shows ash cloud graphs from the Washington VAAC 2002 Volcano Ash Advisory Archive [21] at 18h00 LT (23h00 UTC) on November 3rd 2002, at 10500 and 17000 masl. Model results of visual ash clouds at these levels are 
also shown in Fig. 6. A $1 \mathrm{mg} \mathrm{m}^{-3}$ contour was used to depict the ash cloud for the model results.

At 10500 masl figures $6 \mathrm{a}$ and $6 \mathrm{~b}$ both show the ash plume traveling toward the southwest. Likewise, at 17500 masl figures $6 \mathrm{a}$ and $6 \mathrm{c}$ both show the plume moving towards the east, although the modeled cloud shows less horizontal dispersion. Graphs obtained for other hours were also in good agreement with the VAACs images.

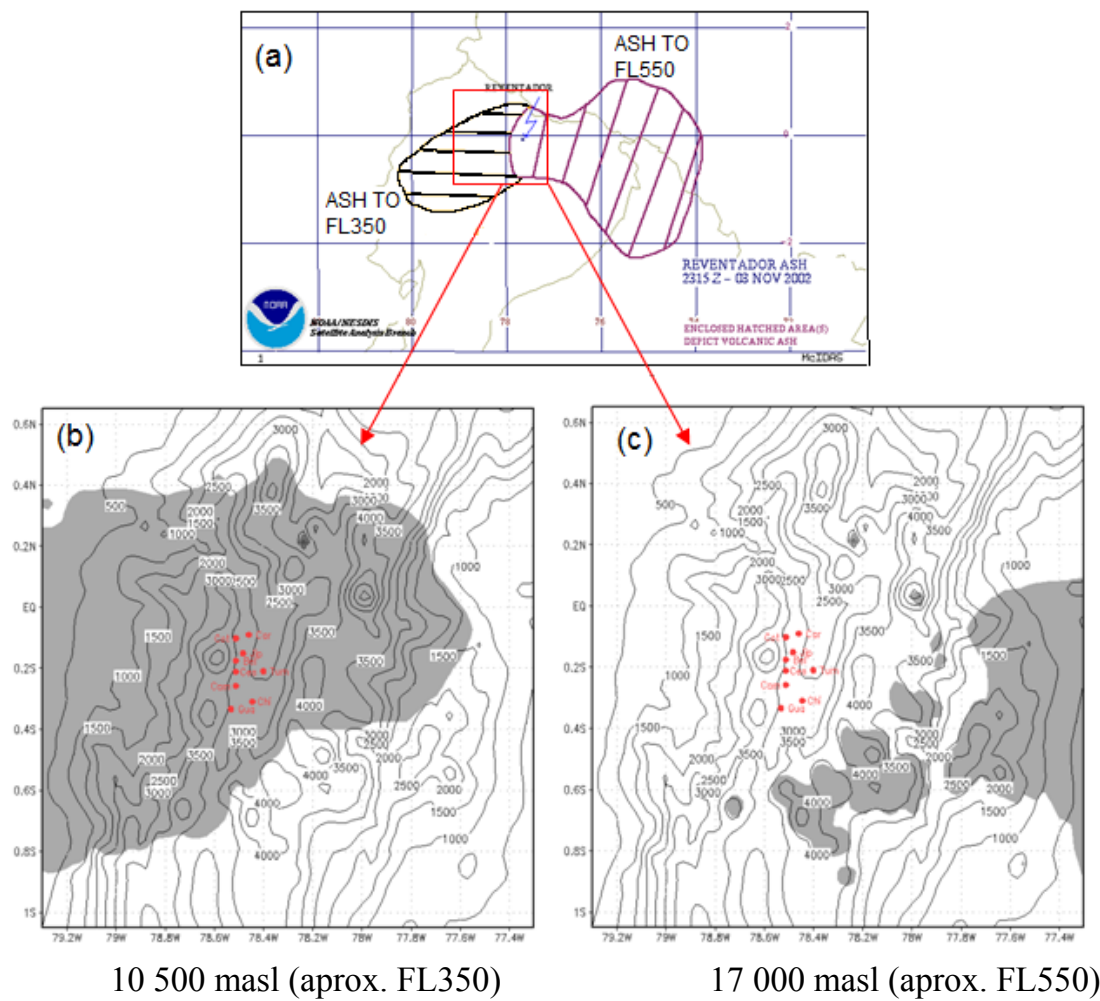

Figure 6: (a) ash cloud graphs at $18 \mathrm{~h} 00 \mathrm{LT}$ (23h00 UTC) on November $3^{\text {rd }}$ 2002 at FL350 and FL550 from the Washington VAAC 2002 archive, (b) and (c) modeled ash cloud shape (gray color, ash concentration larger than $1 \mathrm{mg} \mathrm{m}^{-3}$ ) at 10500 and 17000 masl respectively. Dots show the locations of the air quality stations in Quito, installed in 2003.

\section{Conclusions}

One of the most powerful volcanic events during the last century in Ecuador was the eruption of El Reventador on November 3rd 2002. In this study, the WRF 
and the Fall3d models provided coherent results of ash time arrival and settling pattern due to this event.

Ash dispersion at different altitude levels was well captured by the models. For example, the movement of the ash cloud towards the west, which corresponded to the dispersion of the lower part of the eruptive column, and the dispersion of the upper part towards the east.

This and other volcanic events that have been studied indicate that these coupled models can provide valuable information to track and forecast the dispersion of volcanic ash.

More detailed information of volcanic events at the local scale is required to improve the helpfulness of the information provided by VAAC's advisories. This could be used for a better environmental management in addition to aviation purposes.

\section{Discussion}

Daily modeling of ash dispersion and deposition could be useful as forecast information, especially to be applied to potential cases of simulated unexpected eruptions. Daily forecasts can also become handy when cloudiness does not allow satellite tracking of ash plumes. Such a situation is particularly possible in the Andean region of Ecuador, where convective wet air masses, coming from the coast and the Amazon regions, typically promote the formation of clouds.

A modeling approach can complement the on-site volcanic monitoring of active volcanoes to improve the understanding and management of volcanic ash effects.

The WRF and the Fall3d models today are operated by the Municipality of Quito's Secretariat of Environment. Daily ash cloud dispersion and deposition from El Reventador, Guagua Pichincha and Cotopaxi volcanoes are forecasted assuming that every day eruptions begin at $08 \mathrm{~h} 00 \mathrm{LT}$ and column heights reach 5,10 and $15 \mathrm{~km}$.

WRF and Fall3d can provide ash dispersion maps derived from a typical pattern of wind fields and defined features of ash emission. These maps can be the first tool used to identify regions, cities, towns, facilities, ecosystems and other components that could be affected in case of volcanic ash emissions.

Model results could be used to generate thickness maps for ash layers deposited on the surface, which can become a key element in designing roof structures.

\section{Acknowledgements}

To Dr. María del Carmen Cazorla for her suggestions and for correcting the English. To Dr. Benjamin Bernard for his suggestions.

The numerical simulations were performed in the High Performance Computing system from the Universidad San Francisco de Quito (HPC-USFQ). 


\section{References}

[1] Pan American Health Organization - World Health Organization, Volcanoes: Protecting the public's health, 2002.

[2] Neal, C. \& Guffanti, M., Airbone volcanic ash, a global threat to aviation: U.S. Geological Survey Fact Sheets, 3116, 2010.

[3] Ecogestión, Plan de Contingencias ante Eventuales Episodios de Contaminación Atmosférica en el Distrito Metropolitano de Quito Ecuador, 2008.

[4] Loyola, D., Geffen, J. Van, Valks, P., Erbertseder T., Roozendael, M. Van, Thomas, W., Zimmer, W, Wißkirchen, K, Satellite-based detection of volcanic sulphur dioxide from recent eruptions in Central and South America, Advances in Geosciences, 14, pp. 35-40, 2008.

[5] Delpit, S., Le Pennec, J., Samaniego, P., Hidalgo, S. \& Robin, C., Dynamics of the November 3, 2002 eruption of El Reventador volcano, Ecuador: Insights from the morphology of ash particles, 7th International Symposium on Andean Geodynamics, Nice, Extended Abstracts, pp. 180183, 2008.

[6] Le Pennec, J., Hidalgo, S., Samaniego, P., Ramos, P., Hall, M., Mothes, Chavrit, D. \& Cotten, J., Magnitud de la Erupción del 3 de noviembre del 2002 del Volcán Reventador, Ecuador. Escuela Politécnica Nacional, Terceras Jornadas en Ciencias de la Tierra, Abstract, pp. 94-96, 2003.

[7] Hall, M., Ramón, P., Mothes, P., LePennec, J., García, A., Samaniego, P. \& Yepes, H., Volcanic eruptions with little warning: the case of Volcán Reventador's Surprise November 3, 2002 Eruption, Ecuador, Revista geológica de Chile, 31(2), pp. 349-358, 2004.

[8] Sparks, R., Bursik, M., Carey, S., Gilbert, J. Glaze, L., Sigurdsson, H. \& Woods, A., Volcanic Plumes, John Wiley: Chichester, UK, 1997.

[9] Folch, A., Costa, A., Durant, A. \& Macedonio, G., A Model for Wet Aggregation of Ash Particles in Volcanic Plumes and Clouds: II. Model Application, Journal of Geophysical Research, 115(B9), B09202, doi: 10.1029/2009JB007176, 2010.

[10] Costa, A., Folch, A. and Macedonio, G., A Model for Wet Aggregation of Ash Particles in Volcanic Plumes and Clouds: I. Theoretical Formulation, Journal of Geophysical Research, 115, B09201, doi: 10.1029/ 2009JB007175, 2010.

[11] WRF. The Weather Research \& Forecasting Model, www.wrfmodel.org/index.php

[12] Costa, A., Macedonio, G. \& Folch, A., A three dimensional Eulerian model for transport and deposition of volcanic ashes, Earth and Planetary Science Letters, 241, pp. 634-647, 2006.

[13] Folch, A., Costa, A. \& Macedonio, G., FALL3D: a computational model for transport and deposition of volcanic ash, Computer \& Geosciences, 35(6), pp. 1334-1342, 2009. 
[14] Michalakes, J., Dudhia, J., Gill, D., Henderson, T., Klemp, J., Skamarock, W. \& Wang W., The Weather Research and Forecast Model: Software Architecture and Performance, Proc. of the Eleventh ECMWF Workshop on the Use of High Performance Computing in Meteorology, eds. Walter Zwieflhofer and George Mozdzynski, World Scientific, Reading, pp. 156$168,2004$.

[15] NCEP, NCEP FNL Operational Model Global Tropospheric Analyses, continuing from July 1999, Research Data Archive at the National Center for Atmospheric Research, Computational and Information Systems Laboratory. http://rda.ucar.edu/datasets/ds083.2

[16] Skamarock, W., Klemp, J., Dudhia, J., Barker, D., Duda, M., Huang, X., Wang, W. \& Powers, J., A Description of the Advanced Research WRF Version 3, NCAR/TN-475+STR, NCAR Technical Note, Mesoscale and Microscale Meteorology Division, National Center for Atmospheric Research, Boulder, USA, 2008.

[17] Horwell, C.J., Grain size analysis of volcanic ash for the rapid assessment of respiratory health hazard, Journal of Environmental Monitoring, 9, pp. 1107-1115, 2007.

[18] Suzuki, T., A theoretical model for dispersion of tephra. Arc Volcanism: Physics and Tectonics, ed. Shimozuru, D. \& Yokoyama, I., Terrapub, pp. 95-113, 1983.

[19] Mastin, L.G., Guffani, M., Servranckx, R., Webley, P., Barsotti, S., Dean, K., Durant, A., Ewert, J.W., Neri, A., Rose, W.I., Schneider, D., Siebert, L., Stunder, B., Swanson, G., Tupper, A., Volentik, A. \& Waythomas, C.F., A multidisciplinary effort to assign realistic source parameters to models of volcanic ash-cloud transport and dispersion during eruptions, Journal of Volcanology and Geothermal Research, 186, pp. 10-21, 2009.

[20] NOAA, www.ssd.noaa.gov

[21] VAAC. Washington Volcano Ash Advisory Archive, http://www.ssd.noaa.gov/VAAC/ARCH02/archive.html 